\title{
Reproductive biology of Alvinocaris muricola (Decapoda: Caridea: Alvinocarididae) from cold seeps in the Congo Basin
}

\author{
Eva Ramirez-Llodra $*^{\ddagger}$ and Michel Segonzac ${ }^{\dagger}$ \\ *Institut de Ciències del Mar, CMIMA-CSIC, Psg. Marítim de la Barceloneta 37-49, 08003 Barcelona, Spain. \\ ${ }^{\dagger}$ Ifremer, Centre de Brest, Laboratoire Environnement Profond-Centob, BP 70, 29280 Plouzané Cedex, France. \\ ${ }^{\ddagger}$ Corresponding author, e-mail: ezr@icm.csic.es
}

\begin{abstract}
The caridean shrimp Alvinocaris muricola has been observed forming high density populations over mussel beds on the giant pockmark cold seep site Regab in the Gulf of Guinea at $3150 \mathrm{~m}$ depth. Samples were collected using the ROV Victor 6000, a beam trawl and a TV grab from two sites. The specimens were sexed and measured for population structure analysis. In one sample the sex ratio was 1:1, but the other sample had a sex ratio significantly biased towards females. The maximum size of females is larger than males. A sub-sample was used for gametogenesis and fecundity analysis. The oogenesis and spermatogenesis of A. muricola is characteristic of caridean shrimps. The oogonia proliferate from the germinal epithelium and develop into previtellogenic oocytes that migrate to the growth zone. Vitellogenesis starts at $80-100 \mu \mathrm{m}$ oocyte size and the developing oocytes are surrounded by a monolayer of accessory cells. The maximum oocyte size was $515 \mu \mathrm{m}$. There was no evidence of synchrony in oocyte development, with all oocyte stages present in all ovaries analysed. However, seasonal sampling would be necessary to confirm the lack of seasonality in reproduction. In males, the sperm develops in sperm sacs in the testis. As in all caridean shrimp, the broods of $A$. muricola are held on the pleopods P11 to P14. Total fecundity was related to female size and ranged between 1432 and 5798 embryos. Within a brood all embryos are at the same stage of development, but three different stages were identified in different females, with no clear seasonal trend. The embryos were small, with mean dimensions of $0.66 \times 0.55 \mathrm{~mm}$, suggesting planktotrophic larvae and a potential extended larval development.
\end{abstract}

\section{INTRODUCTION}

The interest on chemosynthetic ecosystems stimulated by the discovery of hydrothermal vents in 1977 was strengthened with the discovery of cold seep communities in the Gulf of Mexico in 1984 and the subsequent findings of chemosynthetically driven communities in other highly reduced sediment habitats (i.e. whale falls, sunken wood and areas of low oxygen intersecting with the continental margin) (Sibuet \& Olu, 1998; Levin, 2003; Smith \& Baco, 2003; Tunnicliffe et al., 2003; Levin, 2005). Cold seeps occur both in geologically passive and active continental margins. These habitats are characterized by the seepage of cold fluids enriched with methane and high concentrations of hydrogen sulphide of microbial origin (Levin, 2005). As in hydrothermal vents, the biological communities in cold seeps are sustained by the production of chemoautotrophic bacteria that use the reduced chemicals in the pore waters as source of energy. These microorganisms are both free-living and symbiotic with the megafauna.

Since the discovery of deep-water chemosynthetic ecosystems, an increasing number of sites and their communities have been described (Tunnicliffe et al., 1998). Approximately 550 species have been identified from hydrothermal vents and surrounding habitat (Desbruyères et al., 2006), while approximately 200 species have been found from cold seeps (K. Olu, personal communication) and over 400 morphological species have been identified from whale falls, but most of which still await taxonomical analysis (Baco \& Smith, 2003). Following the initial discovery phase, the biology and ecology of some of the major species from vents and seeps have been studied (Tunnicliffe et al., 2003). However, the difficulty of regular sampling and of reproducing these natural environments in the laboratory (high pressure in particular) makes it especially arduous to study in detail the physiology of their species. In particular, little is known on certain reproductive aspects (e.g. age at maturity, timing of spawning, larval ecology) of most vent and seep species (Tyler \& Young, 1999). The knowledge of the life history traits of a species is essential to understand its ecology, population dynamics, gene flow and resulting biogeography (Ramirez-Llodra, 2002). Among the life history traits of an organism, fecundity is an important variable because of its relationship with the production and survival potential of offspring and maternal investment in reproduction. The relationship between fecundity and energy budget is based on tradeoffs between number and size of eggs, ranging from the production of a high number of small eggs to the production of a small number of large, rich eggs (McGinley et al., 1987; Stearns, 1992; Ramirez-Llodra, 2002 for a review). Information on sex ratio, gametogenesis, fecundity and egg type is essential to understand the population structure of a species and the environmental and 
ecological factors affecting its continuity. This information together with molecular studies helps understand patterns of gene flow and will result in a better understanding of biogeographical patterns and taxonomic relationships.

In the family Alvinocarididae, endemic to reduced environments, the genus Alvinocaris is represented by nine species. Komai \& Segonzac (2005) have recently produced a thorough revision providing the basis for the taxonomy of this genus. Alvinocaris muricola Williams, 1988, is found in the South Barbados Prism (Olu et al., 1996), the Gulf of Mexico (Williams, 1988), Blake Diapir (Komai et al., 2005) and the Congo Basin (Komai \& Segonzac, 2005), over mussel beds. It is a scavenger on the mussel bed fauna and it has been observed feeding on mussels that had been broken by the articulated arm of the submersible. In spite of the distance separating the Gulf of Guinea and the Gulf of Mexico, these authors did not distinguish any morphological difference between the populations of $A$. muricola in these two areas.

Two cold seep sites have been discovered and explored in the Gulf of Guinea region since 1998 (Figure 1). The Regab site is a giant pockmark north of the Zaïre River canyon, at $3150 \mathrm{~m}$ depth, discovered in 1998 by the
French cruise Zairov (Ondréas et al., 2005). Its faunal composition is similar to that of cold seep sites located in the Pacific and Atlantic Oceans and in the Gulf of Mexico (Tyler et al., 2003), including the siboglinid tubeworm Escarpia southwardae (Andersen et al., 2004), the mytilid Bathymodiolus spp., vesicomyid Calyptogena sp., galatheid crabs (Macpherson \& Segonzac, 2005), caridean shrimp (Komai \& Segonzac, 2005) and the holothurian Chiridota sp. The alvinocaridid shrimps are present in high densities (up to 300 ind $\mathrm{m}^{-2}$ ) among the mytilids and tubeworms (Komai \& Segonzac, 2005). In 2002, a German cruise (M56) explored a site $100 \mathrm{~km}$ north of Regab, with a similar faunal community, except for the absence of mytilid bivalves. Finally, in 2003, a new site bordering the north of Regab was discovered while trawling during the Biozaïre 3 cruise. The presence of several species known to be endemic of cold seeps, including several hundred Alvinocaris muricola, indicated clearly that this sampling took place at least on the edge of the Regab pockmark.

In this paper, we describe patterns of population structure, gametogenesis and fecundity of Alvinocaris muricola from the Gulf of Guinea cold seeps. The results are

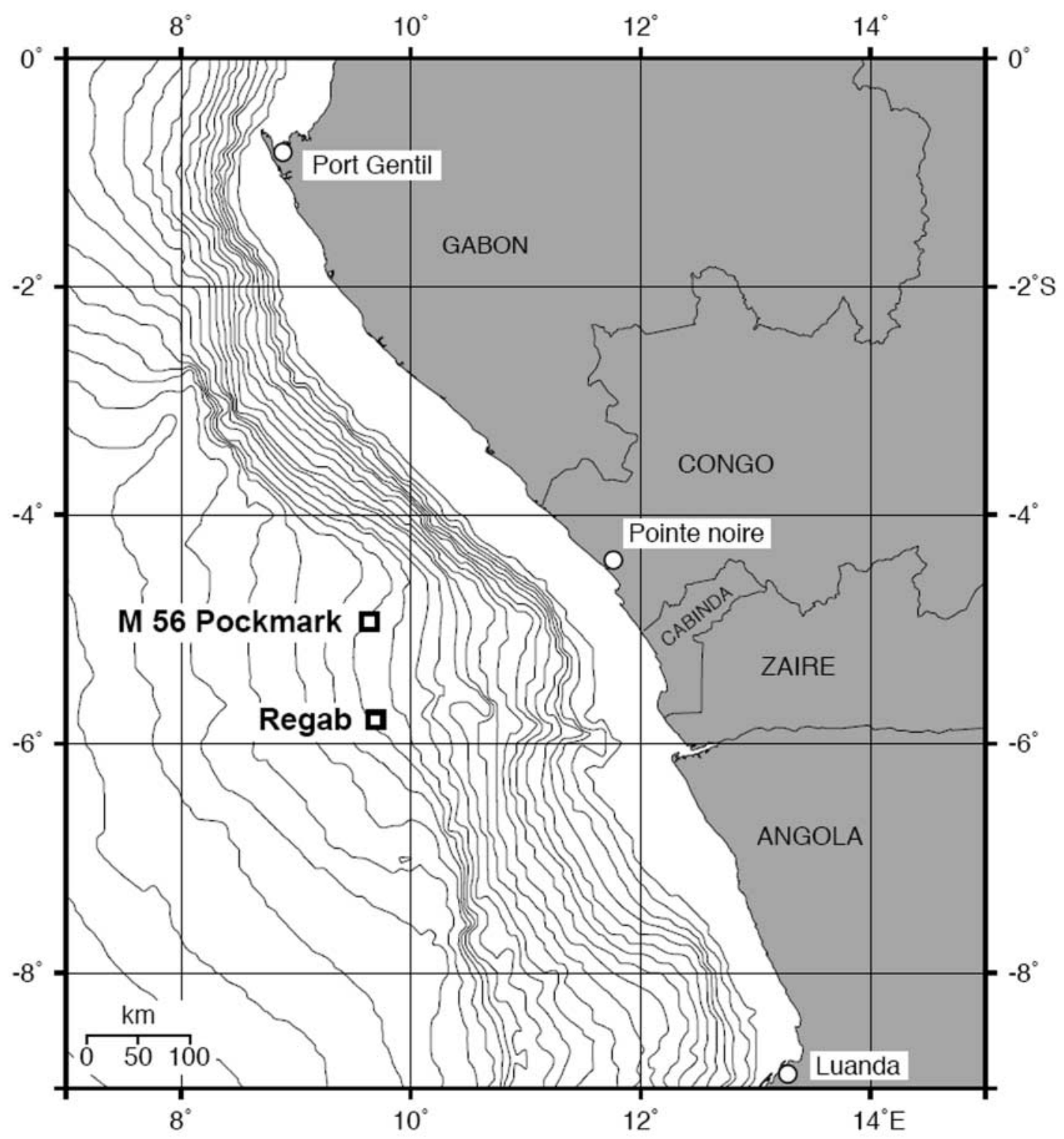

Figure 1. Map showing the location of the sampling sites. 


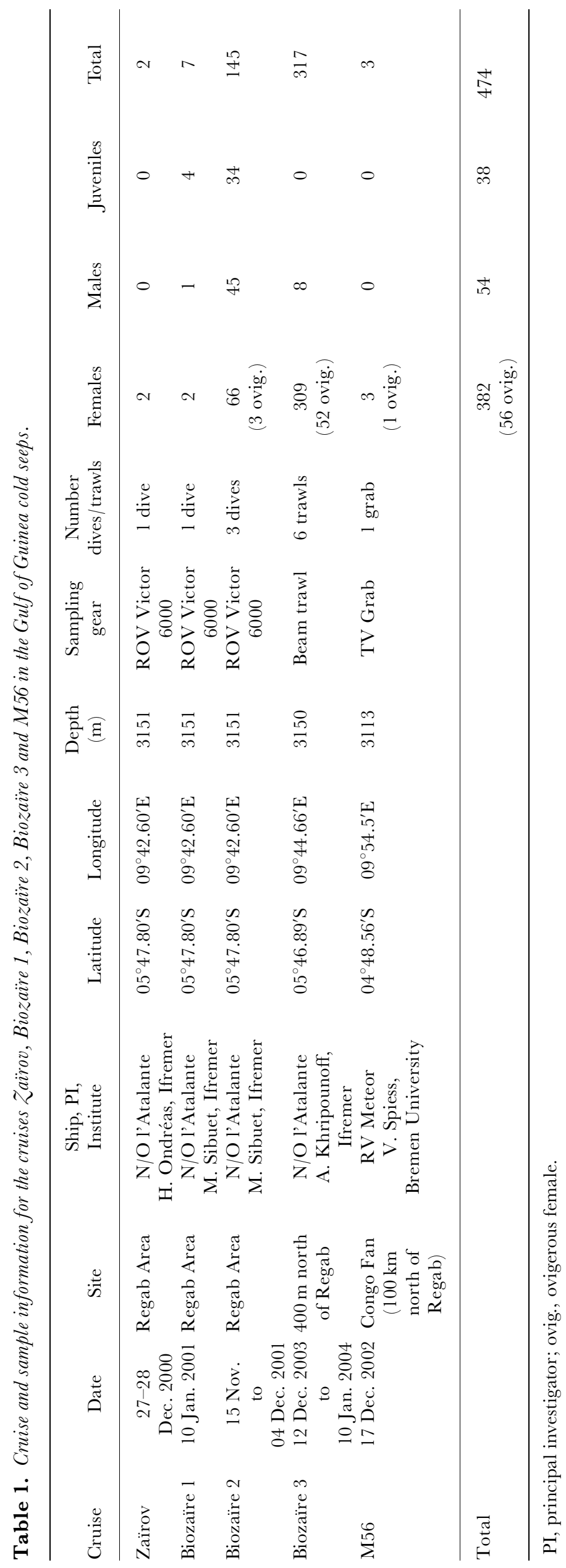



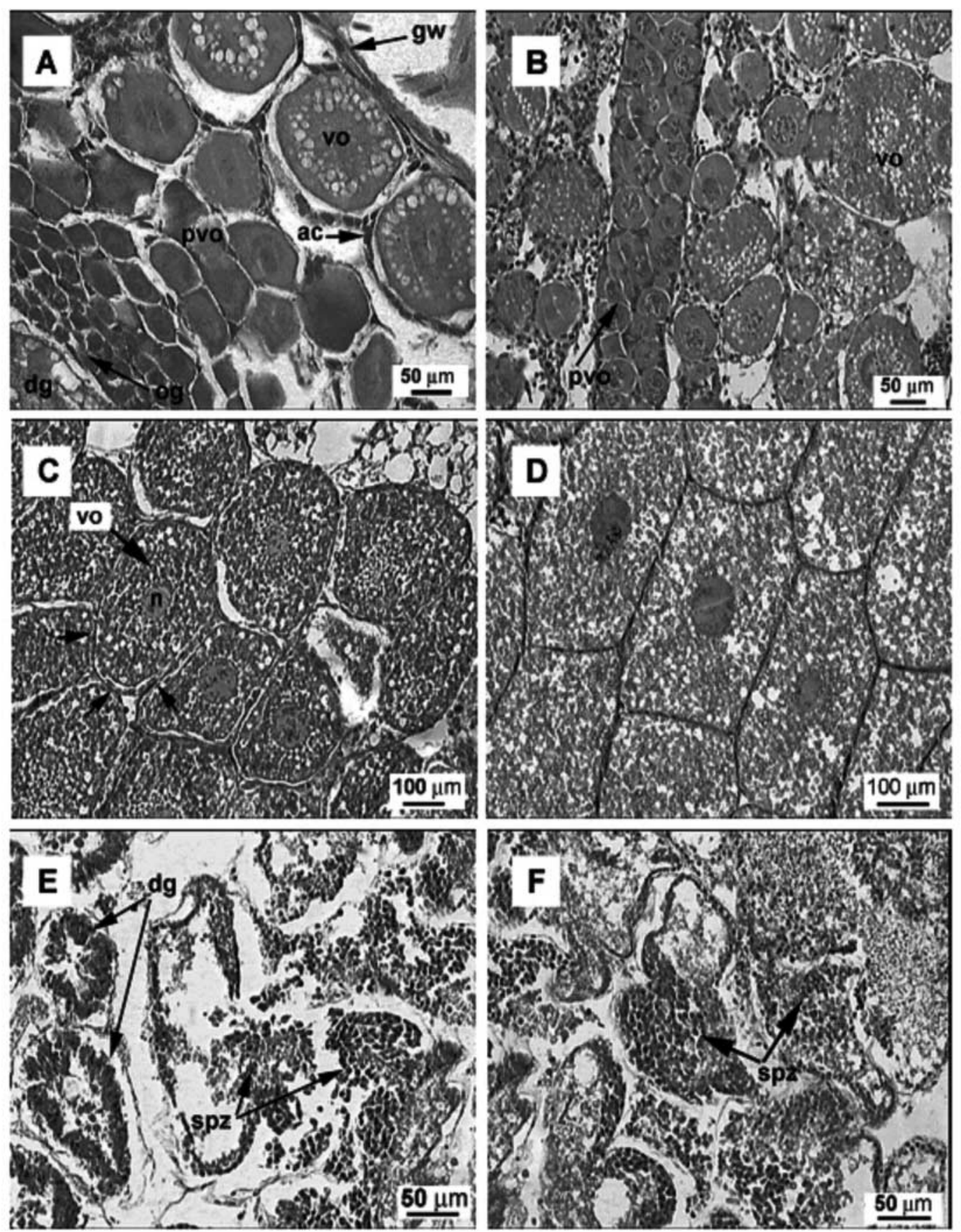

Figure 2. Light histology sections of $(\mathrm{A}-\mathrm{D})$ ovaries and $(\mathrm{E}, \mathrm{F})$ testis of Alvinocaris muricola. ac, accessory cells; dg, digestive gland; gw, gonad wall; n, nucleus; og, oogonia; pvo, previtellogenic oocytes; spz, spermatozoa; vo, vitellogenic oocytes.

discussed and compared with the available data for other alvinocaridid shrimps from cold seeps and hydrothermal vents.

\section{MATERIALS AND METHODS \\ Sampling}

The material studied was collected during five cruises organized by French and German teams to the Regab and M56 sites on the Gulf of Guinea, West African continental margin (Figure 1; Table 1). The description of the Regab area can be found in previous publications (Andersen et al., 2004; Komai \& Segonzac, 2005; Macpherson \& Segonzac, 2005; Ondréas et al., 2005).
The M56 site is described in Komai \& Segonzac (2005), who initially named this site 'Congo Fan'. The samples of Alvinocaris muricola were collected using the slurp gun on the ROV Victor 6000 (Zaïrov, Biozaïre 1 \& 2), a TV grab (TV grab, Station GeoB8212-2, M56) and a beam trawl (CP 20, Biozaïre 3). The samples were fixed in formalin and preserved in $80 \%$ alcohol. The shrimps were identified to the species level in the sorting centre Centob (Ifremer, Brest).

\section{Population data}

A total of 474 specimens was collected (Table 1). All specimens were sexed and carapace length (CL) measured from the posterior margin of the orbit to the midpoint of the posterodorsal margin of the carapace. The CL was 


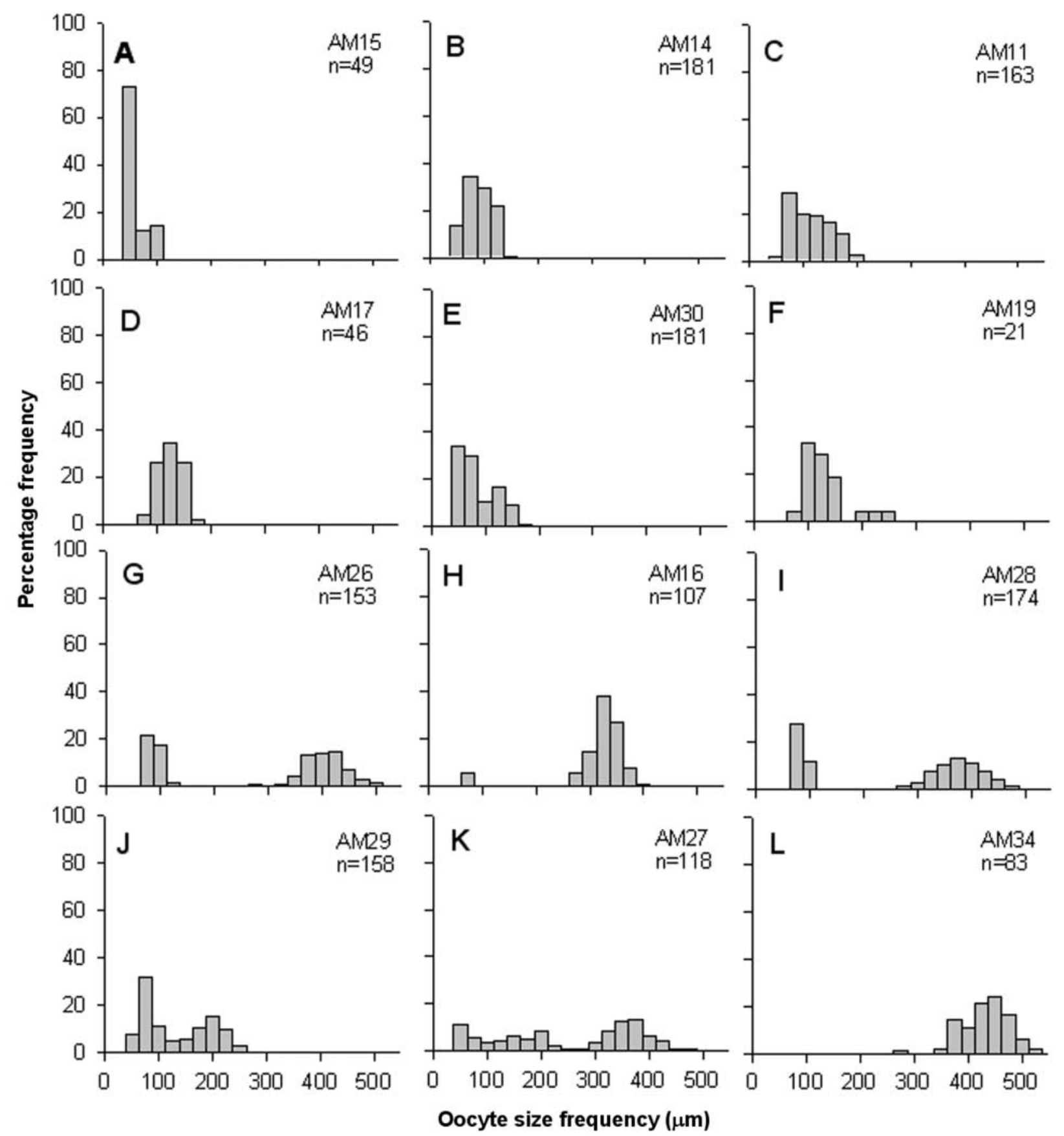

Figure 3. Oocyte size distributions of Alvinocaris muricola. AM, Alvinocaris muricola specimen; n, number of oocytes measured. A-D, F,H: female specimens collected during Biozaïre 2 (November 2001); E, I-L: female specimens collected during Biozaïre 3 (January 2003).

measured to the nearest $0.1 \mathrm{~mm}$ with precise callipers and wet weight was measured to the nearest $0.1 \mathrm{~g}$ with a precise balance after absorption of excess preservative fluid. Sex ratio was estimated and differences from 1:1 ratio analysed with a $\chi^{2}$-test.

\section{Reproduction}

A total of 20 females and 25 males collected during Biozaïre 2 and 3 were used for reproductive analysis. Gametogenesis was studied by analysis of histological sections. The gonads were dissected out, processed for histology, sectioned at $7 \mu \mathrm{m}$ and stained with haematoxylin and eosin. The Feret diameter of all oocytes that had been sectioned through the nucleus was measured using the image analysis package SigmaScanPro4. Oocyte sizes were grouped in $20 \mu \mathrm{m}$ size-classes and oocyte-size-frequency diagrams constructed for each individual.

Size-specific fecundity was used to compare the reproductive output of Alvinocaris muricola with that of other known cold seep and hydrothermal vent shrimp. Fecundity and embryo size were quantified in 11 ovigerous females. The embryo batch was considered complete when the embryos were regularly grouped between the abdominal segments. All embryos were counted directly under a binocular dissecting microscope. Total fecundity is given as number of embryos per female and relative fecundity (size-specific fecundity) is calculated as number of embryos divided by CL. Total fecundity was correlated with carapace length and the Pearson Product Moment Correlation test was applied to the data. The lesser and 
greater diameters of 100 embryos in the broods of 10 females were measured using SigmaScanPro4. Mean embryo diameters were calculated and differences between females analysed using analysis of variance (ANOVA).

\section{RESULTS}

\section{Population data}

Of the 474 specimens analysed, 382 were females, 54 were males and 38 were juveniles (Table 1). The sex ratio in the sample from Biozaïre 2 did not differ significantly from the 1:1 expected with 66 females and 45 males $\left(\chi^{2}=\right.$ $3.973,1 \mathrm{df}, P>0.05)$. On the other hand, the sex ratio from Biozaïre 3 was significantly biased towards females, with 309 females and 8 males $\left(\chi^{2}=285.8,1 \mathrm{df}, P<0.01\right)$.

\section{Gametogenesis}

The ovaries of Alvinocaris muricola are paired organs situated dorsally under the carapace overlying the digestive gland. The ovaries consist of several layers of developing oocytes enveloped by a thin gonad wall. The oogonia proliferate from the germinal epithelium and develop into previtellogenic oocytes (Figure 2A). These migrate to the growth zone between large vitellogenic oocytes, where they undergo vitellogenesis (Figure 2B). The developing oocytes are surrounded by a monolayer of accessory cells (Figure 2A\&G). The previtellogenic oocytes are basophilic (stained dark purple by haematoxylin) and are characterized by a large nucleus/ cytoplasm ratio (Figure $2 \mathrm{~A} \& \mathrm{~B}$ ). Vitellogenesis begins at 80-100 $\mu \mathrm{m}$ oocyte size, revealed by the appearance of

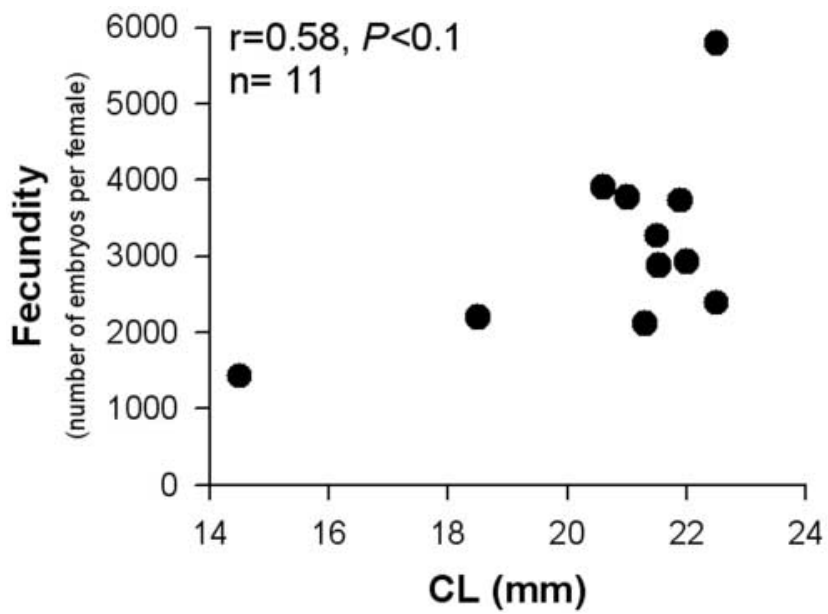

Figure 4. Correlation between total fecundity (number of embryos per female) and carapace length of Alvinocaris muricola. CL, carapace length.

yolk vesicles and a change to acidophilia in the ooplasm, which results in a pink stain (Figure 2C\&D). During vitellogenesis, the growing oocytes accumulate yolk vesicles that spread throughout the ooplasm in mature oocytes (Figure 2D). The average vitellogenic oocyte size varied considerably, ranging from $85.8 \pm 7.8 \mu \mathrm{m}$ in females with newly developing ovaries to $420.8 \pm 43.4 \mu \mathrm{m}$ in well developed ones. The maximum oocyte size was $515 \mu \mathrm{m}$.

The male gonads are also paired structures overlying the digestive gland. In the histological sections, the testis

Table 2. Average fecundity and embryo sizes of different species of caridean shrimp from hydrothermal vents and cold seeps.

\begin{tabular}{|c|c|c|c|c|c|c|c|c|}
\hline \multirow[b]{3}{*}{ Site } & \multirow{3}{*}{$\begin{array}{c}\text { Alvinocaris } \\
\text { muricola } \\
(\mathrm{N}=9) \\
\\
\text { Congo Basin } \\
\text { (seep) }\end{array}$} & \multirow{3}{*}{$\begin{array}{c}\text { Alvinocaris } \\
\text { markensis } \\
(\mathrm{N}=1)\end{array}$} & \multirow{3}{*}{$\begin{array}{l}\text { Alvinocaris lusca } \\
\qquad \begin{array}{c}\mathrm{N}=1) \\
\text { Galapagos } \\
\text { Rift } \\
\text { Pacific } \\
\text { (vent) }\end{array}\end{array}$} & \multicolumn{2}{|c|}{$\begin{array}{l}\text { Alvinocaris } \\
\text { stactophila } \\
(\mathrm{N}=120)\end{array}$} & \multirow{3}{*}{$\begin{array}{c}\begin{array}{c}\text { Mirocaris } \\
\text { fortunata } \\
(\mathrm{N}=30)\end{array} \\
\\
\\
\text { Lucky Strike } \\
\text { MAR } \\
\text { (vent) }\end{array}$} & \multirow{3}{*}{$\begin{array}{c}\begin{array}{c}\text { Chorocaris } \\
\text { chacei } \\
(\mathrm{N}=1)\end{array} \\
\\
\text { Lucky Strike } \\
\text { MAR } \\
\text { (vent) }\end{array}$} & \multirow{3}{*}{$\begin{array}{c}\begin{array}{c}\text { Rimicaris } \\
\text { exoculata } \\
(\mathrm{N}=2)\end{array} \\
\\
\text { Snake Pit } \\
\text { \& TAG } \\
\text { MAR } \\
\text { (vent) }\end{array}$} \\
\hline & & & & $\begin{array}{r}\text { Brine } \mathrm{P} \\
\text { (se }\end{array}$ & $\begin{array}{l}\text { ol GoM } \\
\text { ep) }\end{array}$ & & & \\
\hline & & & & $\mathrm{IMB} N=55$ & $\mathrm{MMB} N=65$ & & & \\
\hline Depth $(\mathrm{m})$ & $3113-3150$ & 1690 & 2500 & \multicolumn{2}{|c|}{500} & 1690 & 1690 & $3480-3650$ \\
\hline $\begin{array}{l}\text { CL }(\mathrm{mm}) \\
\quad \text { Mean } \pm \text { SD }\end{array}$ & $20.7 \pm 2.3$ & 13 & 11.45 & 3.77 & 3.91 & $7.16 \pm 0.18$ & 16.8 & 17.05 \\
\hline $\begin{array}{l}\text { Total Fec. } \\
\quad \text { (embryos) } \\
\text { Mean } \pm \text { SD }\end{array}$ & $3130 \pm 1180.9$ & 2007 & 407 & 147 & 98 & $174.7 \pm 22.8$ & 2510 & 912 \\
\hline $\begin{array}{l}\text { Rel. Fec. } \\
\quad \text { Mean } \pm \text { SD }\end{array}$ & $149.1 \pm 48.0$ & 154 & 35 & 39 & 25 & 24.3 & 149 & 53 \\
\hline $\begin{array}{l}\text { Mean embryo } \\
\text { size }(\mathrm{mm})\end{array}$ & $0.66 \times 0.55$ & $0.66 \times 0.52$ & $0.50 \times 0.34$ & 0.80 & $0.79 \times 0.57$ & $0.70 \times 0.49$ & & $0.72 \times 0.62$ \\
\hline Reference & This paper & $\begin{array}{c}\text { M. Segonzac, } \\
\text { unpublished } \\
\text { data }\end{array}$ & $\begin{array}{l}\text { Van Dover } \\
\text { et al., } 1985\end{array}$ & $\begin{array}{r}\mathrm{Co} \\
\& \mathrm{Y} \\
20\end{array}$ & $\begin{array}{l}\text { ley } \\
06\end{array}$ & $\begin{array}{c}\text { Ramirez- } \\
\text { Llodra et al., } \\
2000\end{array}$ & $\begin{array}{c}\text { Ramirez- } \\
\text { Llodra et al., } \\
2000\end{array}$ & $\begin{array}{c}\text { Williams \& } \\
\text { Rona, 1986; } \\
\text { Ramirez- } \\
\text { Llodra et al., } \\
2000\end{array}$ \\
\hline
\end{tabular}

CL, carapace length; GoM, Gulf of Mexico; IMB, inner mussel bed site and MMB, middle mussel bed site in Brine Pool (from Copley \& Young, 2006); MAR, Mid-Atlantic Ridge; N, number of females analysed; Rel. Fec., relative fecundity (embryos/mm CL); Total Fec., total fecundity (number of embryos per female); SD, standard deviation. 

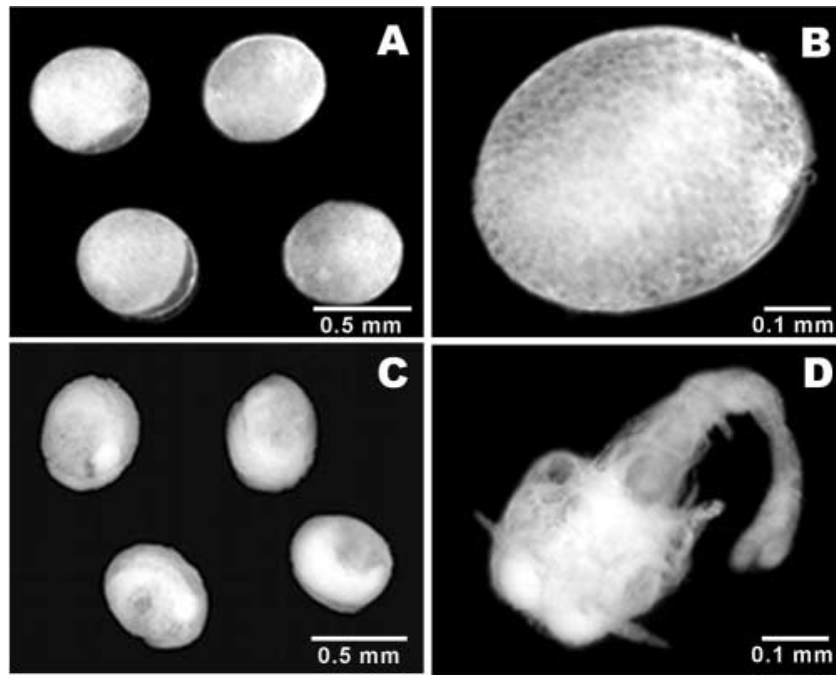

Figure 5. Embryo stages of Alvinocaris muricola. (A) Early embryos; (B) close up of an early embryo; (C) late embryo; (D) recently hatched larva.

shows its lobular morphology. The spermatogonia formed layers of cells lining the gonad wall, but in all the males studied, there were no spermatids or spermatozoa, or only in very few numbers (Figure $2 \mathrm{E} \& \mathrm{~F}$ ).

From the 20 females analysed, we obtained good histological sections of ovaries for 12 individuals. In the remaining eight females analysed, the ovaries were either not well developed or lost during histology because of poor tissue preservation. There was no evidence of synchrony in the ovarian development of the analysed females. Of the 12 females for which we obtained good histological sections, six had mainly previtellogenic and young vitellogenic oocytes measuring between 50 and $200 \mu \mathrm{m}$ (Figure 3A$\mathrm{F}$ ), five of which had been collected in late November 2001 and one (AM30, Figure 3E) in early January 2003. Five females had ovaries with two distinct cohorts of oocytes, with a first peak of previtellogenic and young vitellogenic oocytes $(50-200 \mu \mathrm{m})$ and a second peak of large vitellogenic oocytes larger than $200 \mu \mathrm{m}$ (Figure 3 $\mathrm{G}-\mathrm{K}$ ). Of these, four females had been collected in late December 2003 and two (AM19 and AM16, Figure $3 \mathrm{~F} \& \mathrm{H}$ ) in late November 2001. Finally, one female had a very well developed ovary composed mainly of large vitellogenic oocytes measuring 350 to $500 \mu \mathrm{m}$ (Figure 3L). This female had been collected in late November 2001.

\section{Fecundity}

The embryos in broods of Alvinocaris muricola form a dense mass attached to pleopods 1-4 below the female abdomen. There are between 100 to 1200 embryos per pleopod, with a maximum on pleopods 2 and 3 and minimums on pleopods 1 and 4. Total fecundity ranged from 1432 embryos in the smallest female $(\mathrm{CL}=14.5 \mathrm{~mm})$ to 5798 embryos in the largest female $(\mathrm{CL}=22.5 \mathrm{~mm}$; Figure 4). Larger females tended to have larger broods but the correlation between female size and fecundity was only statistically significant at $P<0.1 \quad(\mathrm{r}=0.58$, $0.05<P<0.1)$. This could have been caused by the small sample size and the lack of data points between $\mathrm{CL}=14.5 \mathrm{~mm}$ and $\mathrm{CL}=18.4 \mathrm{~mm}$, as well as by variation caused by brood damage in larger females. Size-specific

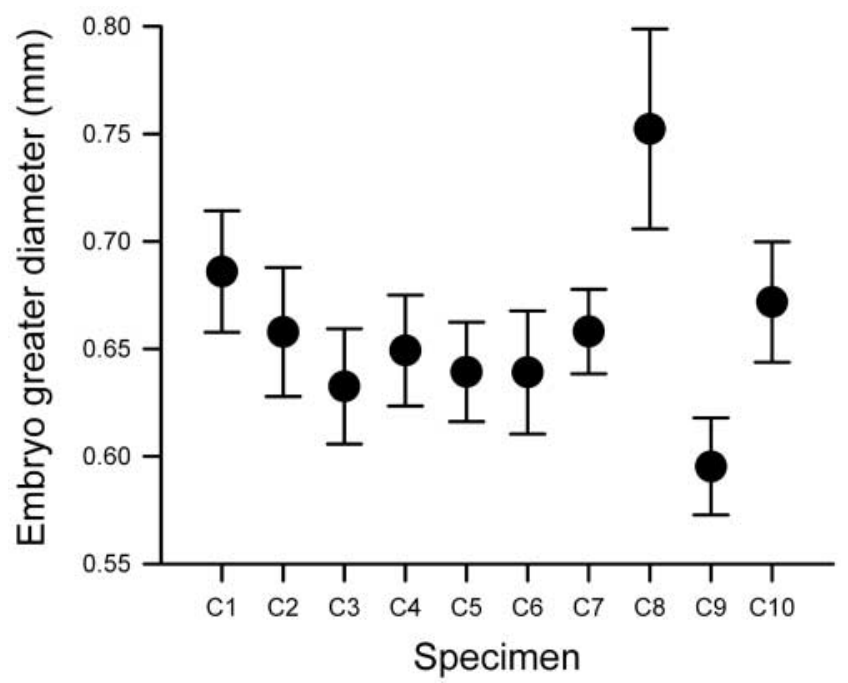

Figure 6. Mean embryo greater diameter from broods of ten Alvinocaris muricola females. Between 53 and 96 embryos were measured for each specimen. Error bars $=$ standard deviation.

fecundity (related to CL) ranged from 99 to 258 embryos $\mathrm{mm}^{-1}$, with an average of $149.1 \pm 48.0$ embryos $\mathrm{mm}^{-1}$ (Table 2).

A small nematode, Chomadorita sp. nov. (Adenophora) was found in small numbers among the embryos of some females and is being studied (A. Vanreusel \& M. Segonzac, unpublished data). One specimen was observed with part of its body inside an embryo, suggesting a predatory action, which could explain the presence of some dark embryos with disrupted development amongst normal embryos.

\section{Embryo sizes}

The broods of the 11 females analysed were in different stages of development, including early embryos with no features i.e. morula aspect (Figure 5A,B), advanced embryos with clear body differentiation (Figure 5C) and embryos ready to hatch with clear larval features such as well developed eyes and abdomen slightly separated from the cephalothorax (Figure 5D). Within the broods, the embryos developed synchronously so all embryos in one batch were at the same stage. The three females from Biozaïre 2 had broods in an advanced stage of development. The female from M56 had embryos in a medium developmental stage. In the sample from Biozaïre 3, four females had embryos in an early developmental stage, one female had embryos in a medium stage and one female had embryos in a very advanced developmental stage with some larvae hatching.

The brooded embryos of Alvinocaris muricola are small, with greater diameter ranging from $0.59 \mathrm{~mm}$ (early development) to $0.75 \mathrm{~mm}$ (late development). There were significant differences in the mean embryo greater diameter amongst females (ANOVA, $F=137.67$, 9df, $P<0.005)$, caused by the female with embryos in an early developmental stage (C9 in Figure 6, diameter $=0.59 \pm 0.02 \mathrm{~mm}$ ) and the female with embryos ready to hatch (C8 in Figure 6, diameter $=0.75 \pm 0.05 \mathrm{~mm}$ ). The mean embryo size in the early development stage was $0.65 \pm 0.02 \mathrm{~mm}$ mean greater diameter and $0.55 \pm 0.02 \mathrm{~mm}$ mean lesser diameter (Table 2; Figure 6). 


\section{DISGUSSION}

The populations of Alvinocaris muricola collected in winter 2004 by trawling in the site north of Regab showed a clear bias towards females. Copley \& Young (2006) have also observed a bias towards females in populations of Alvinocaris stactophila in the inner zone of the Brine Pool (Gulf of Mexico). These authors suggest a specific distribution of males and females within the mussel bed, with ovigerous females avoiding the sulphidic or anoxic extremes in the environment (Copley \& Young, 2006). Such behaviour has also been observed in the hydrothermal vent crab Bythograea thermydron, where the ovigerous females are found in significantly higher abundances at the periphery of the vent site (Perovich et al., 2003). Another explanation for the significantly higher proportion of $A$. muricola females would be protandric hermaphroditism. In some caridean shrimps, the adults can be simultaneous hermaphrodites, where mature females retain the male sexual activity, such as in, for example, species of the genus Lysmata (Baldwin \& Bauer, 2003). However, the spatial distribution of available samples and the data obtained from histological sections were not sufficient to determine the processes causing sex ratio bias in $A$. muricola. The maximum size of females of A. muricola analysed was larger than the maximum size of males. This agrees with Komai \& Segonzac (2005), who compiled data for all specimens of Alvinocaris muricola analysed to date and report a maximum size for females of $\mathrm{CL}=23.6 \mathrm{~mm}$ and for males of $\mathrm{CL}=16.7 \mathrm{~mm}$. The larger size of females is also a common feature in other species of caridean shrimp (Company \& Sardà, 2000).

The gonads of Alvinocaris muricola are similar to that of other caridean shrimp from non-chemosynthetic ecosystems, formed by paired organs laying over the digestive gland in the cephalothorax (Bauer, 2004). The gametogenesis of deep-sea crustaceans is identical to that of their shallow-water relatives (Young, 2003), which supports the hypothesis that gametogenetic patterns are phylogenetically constrained and therefore not affected by environmental conditions (Eckelbarger \& Watling, 1995). The micromorphology of ovaries in A. muricola was similar to that of the three vent shrimps Rimicaris exoculata, Chorocaris chacei and Mirocaris fortunata from the Mid-Atlantic Ridge (Ramirez-Llodra et al., 2000). The developing oocytes are surrounded by a monolayer of accessory cells involved in the vitellogenic processes, which starts at $100 \mu \mathrm{m}$ oocyte diameter. The maximum oocyte size measured was $515 \mu \mathrm{m}$. This size of mature oocytes is again close to that of the vent shrimp from the MAR, which ranged between 300 and $500 \mu \mathrm{m}$ (Ramirez-Llodra et al., 2000). The testis of Alvinocaris muricola was also characteristic of caridean shrimp, with a lobular morphology. There were layers of spermatogonia lining the gonad wall, but no males presented fully developed gonads so the lumen of the testis lobes were empty or had only sparse spermatids. This would indicate that the sperm had been packed in the spermatophores and the males were ready for copulation. The few observations of sparse spermatids in some individuals showed that $A$. muricola has aflagellate sperm typical of all crustaceans. These non-motile male gametes are an adaptation for fertilization through copulation (Bauer, 2004).
The majority of deep-sea species from non-chemosynthetic habitats have continuous or quasi-continuous reproduction, but there are examples of seasonally reproducing species at all latitudes and to depths reaching several thousand metres (Young, 2003). In chemosynthetic habitats, the known data (Tyler \& Young, 1999) indicate that most species from vents and seeps are continuous breeders and it has been suggested that these rich environments can provide the necessary energy to sustain asynchronous or quasi-continuous production of eggs. However, seasonal reproduction has been documented from chemosynthetic habitats in the bivalves Bathymodiolus puteoserpentis and $B$. azoricus in the Mid-Atlantic Ridge, B. childressi from Gulf of Mexico seeps and Calyptogena kilmeri from the Monterey Canyon seeps (see Tyler \& Young, 1999 for references). Recently, a study by Copley \& Young (2006) gives evidence for the first time of seasonal reproduction in an alvinocaridid shrimp, Alvinocaris stactophila, from the Brine Pool seeps (700 m depth) in the Gulf of Mexico, with spawning in November (Copley \& Young, 2006). The first results obtained for A. muricola from the Gulf of Guinea showed females from November 2001 (Biozaïre 2) with earlier stages of ovarian development than females from January 2004 (Biozaïre 3). However, only samples from November to early January could be analysed, so the available data is not sufficient to determine the timing of the reproductive cycle in this species. In addition, all females had oocytes in all stages of development, all samples had ovigerous females and there was no synchrony of embryo development within samples. These data suggest a continuous egg production with periodic spawning events, but larger samples spanning several seasons of the year are necessary to describe the potential periodicity or even seasonality of this species.

In $A$. muricola, larger females tended to carry larger broods (ranging from 1432 to 5798 embryos per female). This is characteristic of decapod crustaceans, where the production of eggs is physically limited by the size of the cephalothorax (Corey \& Reid, 1991). The average sizespecific fecundity was $\sim 150$ embryos $\mathrm{mm}^{-1}$. This value is similar to the size-specific fecundity of Alvinocaris markensis (M. Segonzac, unpublished data) and Chorocaris chacei (Ramirez-Llodra et al., 2000) from the Mid-Atlantic Ridge, but higher than that of $A$. lusca from the Galápagos Rift (Van Dover et al., 1985), A. stactophila from the Gulf of Mexico seeps (Copley \& Young, 2006) and Mirocaris fortunata and Rimicaris exoculata from the MAR (RamirezLlodra et al., 2000; Table 2). There seems to be two distinct trends in size-specific fecundity of carideans from chemosynthetic habitats: one group with values around 150 embryos $\mathrm{mm}^{-1}$ and a second group with values between 25 and 55 embryos $\mathrm{mm}^{-1}$. However, it is the trade-off between fecundity and embryo size that represents the amount of energy allocated to the production of oogenic material, which affects offspring production and survival (Stearns, 1992). But the size-specific investment in reproduction (fecundity $\times$ embryo size) in all these caridean shrimp (Table 2) is difficult to interpret, because there is no clear relationship with either phylogeny, depth or habitat type (vent vs seep). Alvinocaris stactophila and Mirocaris fortunata produce the larger embryos and have the lowest size-specific fecundity (Copley \& Young, 2006; Ramirez-Llodra et al., 2000), suggesting a higher 
investment per embryo and higher individual larval survival. On the contrary, A. muricola produces a high number of embryos in the lower range $(0.66 \times 0.55 \mathrm{~mm})$ of embryo sizes for caridean shrimp. This small size of embryos is indicative of planktotrophic larvae with extended development that must feed in the water column to obtain the necessary energy from the several larval instars to postlarva (Bauer, 2004). One of the major consequences of extended larval development is a higher dispersal and colonization potential, but also a higher larval mortality risk. The production of large embryos that result in large larvae with abbreviated development and/or lecithotrophic larvae has been suggested as an adaptation in deep-sea and high-latitude species to decrease mortality risk in the water column (Bauer, 2004; references within Ramirez-Llodra, 2002). However, of all described alvinocaridid shrimp from chemosynthetic habitats, data on egg sizes is available only for a few species (Table 2), all of which have small embryos with a suggested extended development. This could be a selection for long dispersal time in a habitat characterized by its patchiness and high dynamism with catastrophic events.

The relationships between egg size, larval type and dispersal potential are essential to understanding biogeographical patterns. Even so, the larval phase is one of the least known steps in the life cycle of most deep-sea species (Young, 2003). The planktotrophic larval development of Alvinocaris muricola suggests that this species can disperse and colonize sites geographically distant. Alvinocaris muricola is found at both sides of the Atlantic and recent genetic analyses have confirmed that the Gulf of Mexico and Gulf of Guinea populations belong to the same species (S. Hourdez, unpublished data). Taxonomical data, both morphological and molecular, have given evidence of wide geographical distributions for several other species from chemosynthetically-driven habitats, such as vesicomyid clams (Peek et al., 2000), modiolid mussels (Gustafson et al., 1998; Van Dover et al., 2002) and siboglinid tubeworms (Andersen et al., 2004). However, the processes driving these distributions are mostly unknown. The interactions between environmental abiotic factors (deep-water currents, geological barriers and distance between sites) and larval characteristics (larval type, behaviour, swimming capabilities, mortality rate) are determinant in gene flow and colonization patterns (Cowen et al., 2000; Queiroga \& Blanton, 2005; Mullineaux et al., 2005). In the case of alvinocaridid shrimp, the morphological, genetic and biochemical data available on larvae and juveniles of some species indicate that the planktotrophic larvae migrate upwards in the water column and feed on organic matter produced in the photic zone (Pond et al., 1997a; Shank et al., 1998; Herring \& Dixon, 1998). It has been suggested that this vertical movement during dispersal could explain the broad geographical distribution of certain species with feeding larvae entrained in deep-water currents (Van Dover et al., 2002). In the Atlantic, it has been proposed that the eastward branch of the North Atlantic Deep Water current flowing through the Romanche and Chain fracture zones (Messias et al., 1999) could provide a dispersal pathway for larvae from the Gulf of Mexico to the Western African margin, on a decadal scale and via stepping stone habitats (Van Dover et al., 2002). Velocity profile studies on the equatorial Atlantic indicate the presence of deep jets related to the Antarctic Intermediate Water and North Atlantic Deep Water layers, with velocities up to $10-20 \mathrm{~cm} \mathrm{~s}^{-1}$ (Schmid et al., 2005) that could increase the velocity of larval transport. However, the effect on larval retention of local hydrodynamics at vents and seeps (Thomson et al., 2003; Mullineaux et al., 2005), the decrease in the concentration of larvae by diffusion and mortality during dispersal (Cowen et al., 2000) and the decadal time-scale for transportation of passive particles across the Atlantic (Messias et al., 1999; Arhan et al., 2003) are not favourable to the hypothesis of long-distance larval dispersal for Alvinocaris muricola. In addition, paleophylogeography factors and the role of vent and seep habitats in the distribution of extant alvinocaridid shrimp also need to be taken into account when investigating the phylogeny and biogeography of this group. Molecular studies (COI) indicate that the alvinocaridid shrimp radiated in the Miocene from a vent-like ancestor that gave rise to the seep lineage Alvinocaris stactophila, but further data from other seep species, such as A. muricola, are necessary to understand the role played by seep habitats in alvinocaridid evolution (Shank et al., 1999). Detailed phylogeographic studies and investigations on larval lifespan and mortality during dispersal combined with hydrographic information (including paleo-hydrography) are essential to determine the potential dispersal of vent and seep larvae across the tropical Atlantic. These complex scientific questions are being addressed by the Atlantic Equatorial Belt field programme of the ChEss (Census of Marine Life) initiative, which aims at understanding the diversity and distribution of species from chemosynthetic habitats along a longitudinal gradient in the Equatorial Atlantic, from the Gulf of Mexico to the north-west African continental margin, and to understand the forces driving these biodiversity patterns.

The authors would like to thank the principal scientists, the officers and crew of RV 'l'Atalante' and 'Meteor', and ROV Victor 6000 for collecting specimens: H. Ondréas, Ifremer, Brest (Zairov), M. Sibuet, Ifremer (Biozaïre 2), A. Khripounoff, Ifremer (Biozaïre 3), V. Spiess, University, Bremen, Germany (M56). We would also like to thank H. Sahling, (Research Center Ocean Margins, Germany) for providing specimens for this study, T. Komai (Natural History Museum and Institute, Chiba, Japan) for the identification of the first specimens, S. Hourdez (Station Biologique, Roscoff) for communication of his molecular analysis data, and V. Martin (Ifremer) for the map in Figure 1. Special thanks to Alexis Fifis for measurements of embryos at Ifremer. The material of the cruises Biozaïre 2 and 3 was obtained through the framework of the multidisciplinary environmental programme BIOZAÏRE in partnership between Ifremer and the Oil Company Total. Eva Ramirez-Llodra is funded by the A.P. Sloan Foundation within the Census of Marine Life - ChEss (Chemosynthetic Ecosystems) programme.

\section{REFERENCES}

Andersen, A., Hourdez, S., Marie, B., Jollivet, D., Lallier, F. \& Sibuet, M., 2004. Escarpia southwardae sp. nov., a new species of vestimentiferan tubeworm (Annelida, Siboglinidae) from WestAfrican cold seeps. Canadian Fournal of Zoology, 82, 980-999.

Arhan, M., Mercier, H. \& Park, Y.-H., 2003. On the deep water circulation of the eastern South Atlantic Ocean. Deep-Sea Research I, 50, 889-916. 
Baco, A.R. \& Smith, C.R., 2003. High biodiversity levels on deepsea whale skeletons. Marine Ecology Progress Series, 260, 109-114.

Baldwin, A.P. \& Bauer, R.T., 2003. Growth, survivorship, life-span and sex change in the hermaphroditic shrimp Lysmata wurdemanni (Decapoda: Caridea: Hippolytidae). Marine Biology, 143, 157-166.

Bauer, R.T., 2004. Remarkable shrimps: adaptations and natural history of Carideans. Norman: University of Oklahoma Press.

Company, J.-B. \& Sardà, F., 2000. Growth parameters of deepwater decapod crustaceans in the northwestern Mediterranean Sea: a comparative approach. Marine Biology, 136, 79-90.

Copley, J.T.P. \& Young, C.M., 2006. Seasonality and zonation in the reproductive biology and population structure of the shrimp Alvinocaris stactophila (Caridea: Alvinocarididae) at a Louisiana Slope cold seep. Marine Ecology Progress Series, 315, 199-209.

Corey, S. \& Reid, D.M., 1991. Comparative fecundity of decapod crustaceans. I. The fecundity of thirty-three species of nine families of Caridean shrimp. Crustaceana, 60, 270-294.

Cowen, R.K., Lwiza, K.M.M., Sponaugle, S., Paris, C.B. \& Olson, D.B., 2000. Connectivity of marine populations: open or closed? Science, New York, 287, 857-859.

Desbruyères, D., Segonzac, M. \& Bright, M., ed., 2006. Handbook of hydrothermal vent fauna. Second completely revised edition. Denisia, 18, 1-544.

Eckelbarger, K.J. \& Watling, L., 1995. Role of phylogenetic constraints in determining reproductive patterns in deep-sea invertebrates. Invertebrate Biology, 114, 256-269.

Gustafson, R.G., Turner, R.D., Lutz, R.A. \& Vrijenhoek, R.C., 1998. A new genus and five new species of mussels (Bivalvia, Mytilidae) from deep-sea sulfide/hydrocarbon seeps in the Gulf of Mexico. Malacologia, 40, 63-112.

Herring, P.J. \& Dixon, D.R., 1998. Extensive deep-sea dispersal of postlarval shrimp from a hydrothermal vent. Deep-Sea Research I, 45, 2105-2118.

Komai, T. \& Segonzac, M., 2005. A revision of the genus Alvinocaris Williams and Chace (Crustacea: Decapoda: Caridea: Alvinocarididae), with descriptions of a new genus and a new species of Alvinocaris. Fournal of Natural History, 39, 1111-1175.

Komai, T., Shank, T.M. \& Van Dover, C.L., 2005. A new species of Alvinocaris (Crustacea: Decapoda: Caridea: Alvinocarididae) and a new record of $A$. muricola from methane seeps on the Blake Ridge Diapir, Northwestern Atlantic. Zootaxa, 1019, 27-42.

Levin, L.A., 2003. Oxygen minimum zone benthos: adaptation and community response to hypoxia. Oceanography and Marine Biology. Annual Review, 41, 1-45.

Levin, L.A., 2005. Ecology of cold seep sediments: interactions of fauna with flow, chemistry and microbes. Oceanography and Marine Biology. Annual Review, 43, 1-46.

Macpherson, E. \& Segonzac, M., 2005. Species of the genus Munidopsis (Crustacea, Decapoda, Galatheidae) from the deep Atlantic Ocean, including cold-seep and hydrothermal vent areas. Zootaxa, 1095, 1-60.

McGinley, M.A., Temme, D.H. \& Geber, M.A., 1987. Parental investment in offspring in variable environments: theoretical and empirical considerations. American Naturalist, 130, 370-398.

Messias, M.J., Andrié, C., Memery, L. \& Mercier, H., 1999. Tracing the North Atlantic Deep Water through the Romanche and Chain fracture zones with chlorofluoromethanes. Deep-Sea Research I, 46, 1247-1278.

Mullineaux, L.S., Mills, S.W., Sweetman, A.K., Beaudreau, A.H., Metaxas, A. \& Hunt, H.L., 2005. Vertical, lateral and temporal structure in larval distributions at hydrothermal vents. Marine Ecology Progress Series, 293, 1-16.

Olu, K., Sibuet, M., Harmegnies, F., Foucher, J.-P. \& FialaMedioni, A., 1996. Spatial distribution of diverse cold-seep communities living on various diapiric structures of the southern Barbados prism. Progress in Oceanography, 38, 347-376.

Ondréas, O. et al., 2005. ROV study of a giant pockmark on the Gabon continental margin. Geo-Marine Letters, 25, 281-292.
Peek, A.S., Gaut, B.S., Feldman, R.A., Barry, J.P., Kochevar, R.E., Lutz, R.A. \& Vrijenhoek, R.C., 2000. Neutral and non neutral mitochondrial genetic variation in deep sea clams from the family Vesicomyidae. Fournal of Molecular Evolution, 50, 141-153.

Perovich, G.M., Epifanio, C.E., Dittel, A.I. \& Tyler, P.A., 2003. Spatial and temporal patterns in development of eggs in the vent crab Bythograea thermydron. Marine Ecology Progress Series, 251, 211-220.

Pond, D.W., Dixon, D.R. \& Sargent, J., 1997a. Wax-ester reserves facilitate dispersal of hydrothermal vent shrimps. Marine Ecology Progress Series, 146, 289-290.

Queiroga, H. \& Blanton, J., 2005. Interactions between behaviour and physical forcing in the control of horizontal transport of decapod crustacean larvae. Advances in Marine Biology, 47, 107-214.

Ramirez-Llodra, E., 2002. Fecundity and life-history strategies in marine invertebrates. Advances in Marine Biology, 43, 88-170.

Ramirez-Llodra, E., Tyler, P.A. \& Copley, J.T.P., 2000. Reproductive biology of three caridean shrimp, Rimicaris exoculata, Chorocaris chacei and Mirocaris fortunata (Caridea: Decapoda), from the hydrothermal vents. Fournal of the Marine Biological Association of the United Kingdom, 80, 473-484.

Schmid, C., Bourlès, B. \& Gouriou, Y., 2005. Impact of the equatorial deep jets on estimates of zonal transports in the Atlantic. Deep-Sea Research II, 52, 409-428.

Shank, T.M., Black, M.B., Halanych, K.M., Lutz, R.A. \& Vrijenhoek, R.C., 1999. Miocene radiation of deep-sea hydrothermal vent shrimp (Caridea: Bresiliidae): evidence from mitochondrial Cytochrome Oxidase Subunit I. Molecular Phylogenetics and Evolution 13, 244-254.

Sibuet, M. \& Olu, K., 1998. Biogeography, biodiversity and fluid dependence of deep-sea cold-seep communities at active and passive margins. Deep-Sea Research II, 45, 517-567.

Smith, C. \& Baco, A., 2003. The ecology of whale falls at the deep-sea floor. Oceanography and Marine Biology. Annual Review, 41, 311-354.

Stearns, S.C., 1992. The evolution of life histories. Oxford: Oxford University Press.

Tunnicliffe, V., Juniper, K.S. \& Sibuet, M., 2003. Reducing environments of the deep-sea floor. In Ecosystems of the World. Vol. 28. Ecosystems of the deep oceans (ed. P.A. Tyler), pp. 81-110. London: Elsevier.

Tunnicliffe, V., McArthur, A.G. \& McHugh, D., 1998. A biogeographical perspective of the deep-sea hydrothermal vent fauna. Advances in Marine Biology, 34, 353-442.

Tyler, P.A., German, C.R., Ramirez-Llodra, E. \& Van Dover, C.L., 2003. Understanding the biogeography of chemosynthetic systems. Oceanologica Acta, 25, 227-241.

Tyler, P.A. \& Young, C.M., 1999. Reproduction and dispersal at vents and cold seeps. Fournal of the Marine Biological Association of the United Kingdom, 79, 193-208.

Van Dover, G.L., Factor, J.R., Williams, A.B. \& Berg, C.J. Jr, 1985. Reproductive patterns of decapod crustaceans from hydrothermal vents. Bulletin of the Biological Society of Washington, 6, 223-227.

Van Dover, C.L., German, C.R., Speer, K.G., Parson, L.M. \& Vrijenhoek, R.C., 2002. Evolution and biogeography of deepsea vent and seep invertebrates. Science, New York, 295, 1253-1257.

Wickins, J.F., 1976. Prawn biology and culture. Oceanography and Marine Biology. Annual Review, 14, 435-507.

Williams, A.B., 1988. New marine decapod crustaceans from waters influenced by hydrothermal, discharge, brine and hydrocarbon seepage. Fishery Bulletin, 86, 263-287.

Young, C.M., 2003. Reproduction, development and life history traits. In Ecosystems of the World. Vol. 28. Ecosystems of the deep oceans (ed. P.A. Tyler), pp. 381-426. London: Elsevier. 